\title{
Antibacterial Activity of Glycine max L. Seeds Using Different Extracts
}

\author{
Firas Abbas Al-Bayati \\ Department of Biology / College of Education \\ University of Mosul
}

Received

19/12/2006
Accepted

21/02/2007

الخلاصة

في هذه الدرلمة قم التحري عن التأثير المثط لثلاث مستخلصك من بذور نبلت فول

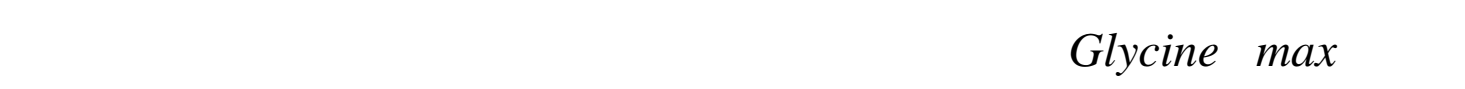
، Klebsiella pneumoniae ، Bacillus cereus ، Staphylococcus aureus ب Pendomonas aeruginosa

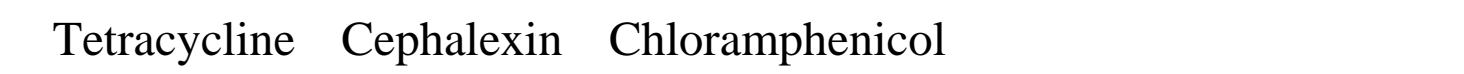
Gentamycin

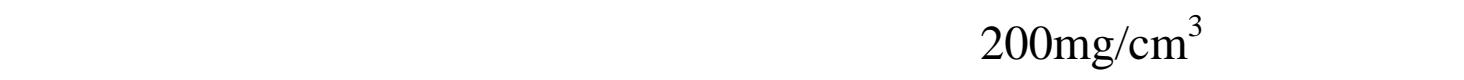

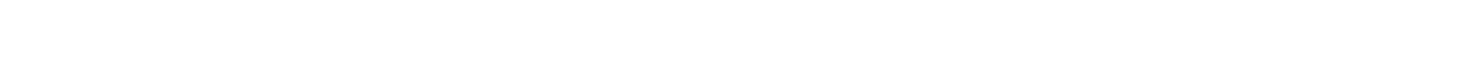

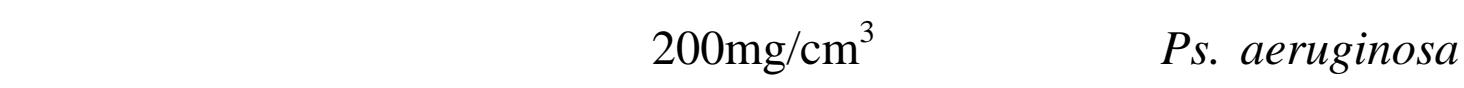
B. cereus

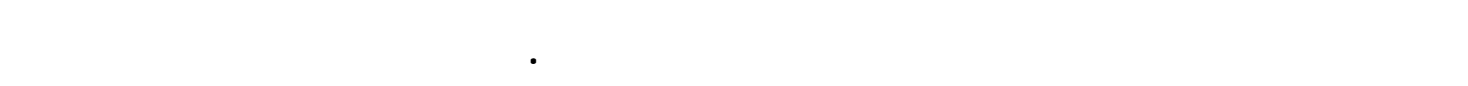
كان مرتبطا بصورة علمة بزياة تركيز المستخلصك المختلفة المالف

\section{Abstract}

In the present study, antibacterial properties of three different extracts from Glycine max L. seeds were screened against four types of Gram-positive and negative bacteria Staphylococcus aureus, Bacillus cereus, Klebsiella pneumoniae and Pseudomonas aeruginosa using agarwell diffusion method and comparing with standard antibiotics Chloramphenicol, Cephalexin, Tetracycline and Gentamycin. The ethanol extract demonstrated good inhibitory effects against most tested bacteria using the extract concentration $200 \mathrm{mg} / \mathrm{cm}^{3}$ compared with chloroform and petroleum ether extracts which gave clear inhibitory effect against $P s$. aeruginosa using the same extract concentration the study also revealed 
the complete resistance of $B$. cereus towards chloroform and petroleum ether extracts but was inhibited using all ethanol extract concentrations and the proportion between inhibitory effect and extract concentration was direct.

\section{Introduction}

Nature has provided a source of medicinal agents for thousands of years and an impressive number of modern drugs have been isolated from natural sources, many based on their use in traditional medicine [1]. The interest in the study of medicinal plants as a source of pharmacologically active compounds has increased worldwide. It is recognized that in some developing countries, plants are the main medicinal source to treat infectious diseases [2]. Plant extracts represents a continuous effort to find new compounds with the potential to act against multi-resistant bacteria. Approximately $20 \%$ of the plants found in the world have been submitted to pharmacological or biological test, and a substantial number of new antibiotics introduced on the market are obtained from natural or semi synthetic resources [3].

Glycine max L. (Soybean) is a subtropical plant (Figure 1), native to Asia. This member of the pea family (Fabaceae) grows from one to five feet tall and forms clusters of three to five pods, each containing two to four beans per pod. Soy has been a dietary staple in Asian countries for at least 5,000 years. The seed (Figure 2) contains up to $20 \%$ of an edible oil that has a very wide range of applications and is commonly used in the chemical industry, manufacturing of paints, linoleum, oilcloth, printing inks, soap, insecticides, and disinfectants [4].

Soybean, a staple food in many Asian countries, contains valuable constituents, including protein, isoflavones, saponins, and phytosterols. Soybean protein provides most of the essential amino acids. It's also low in fat and cholesterol-free. The isoflavones in soybean, primarily genistein and daidzein, have been well researched by scientists for their antioxidant and phytoestrogenic properties. Saponins enhance immune function and bind to cholesterol to limit its absorption in the intestine. Phytosterols and other components of soy have been reported to lower cholesterol levels. Isoflavones may reduce the risk of hormone-dependent cancers, such as breast and prostate cancer, as well as other cancers. Both animal and human studies have confirmed this [5].

Old Chinese herbals suggest that the soybean was a specific remedy for the proper functioning of the bowels, heart, kidney, liver, and

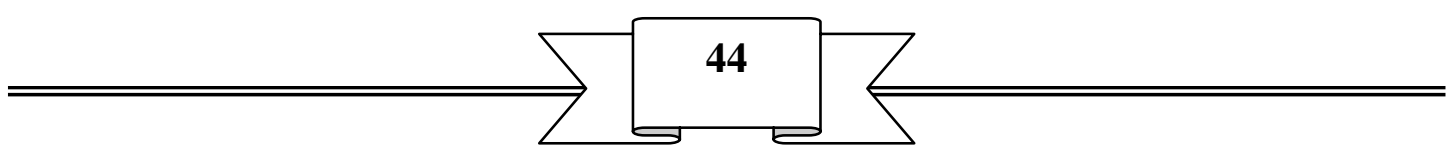




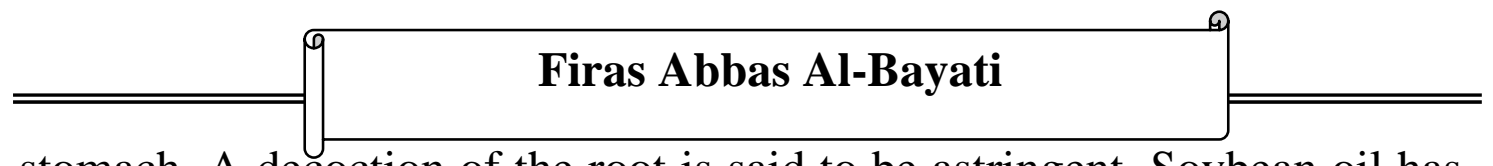

stomach. A decoction of the root is said to be astringent. Soybean oil has a high proportion of unsaturated fatty acid, and contain considerable levels of phenolic compounds. Commercial grades of natural lecithin, often derived from soybean, are reported to contain a potent vasodepressor [6]. Medicinally lecithin is indicated as a lipotropic agent.

Soybean is listed as a major starting material for stigmasterol, once known as an antistiffness factor. Sitosterol, also a soy byproduct, has been used to replace diosgenin in some antihypertensive drugs [7].

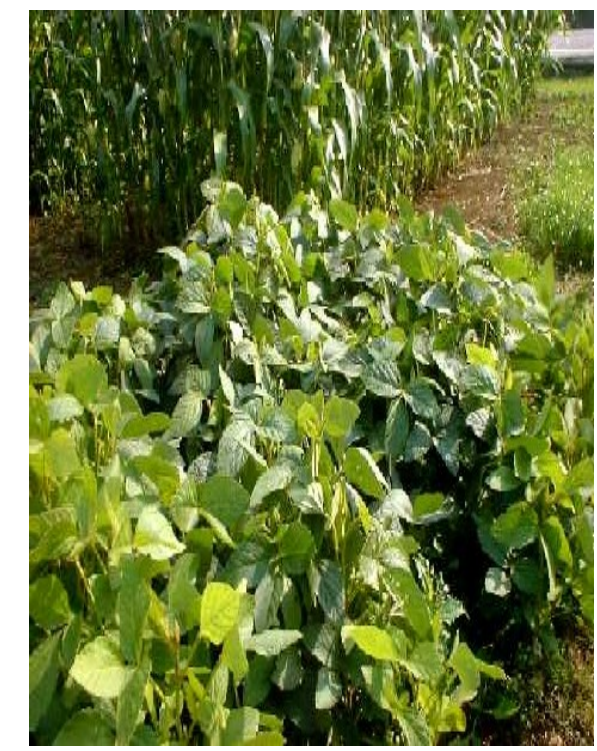

Figure 1: Glycine max plant

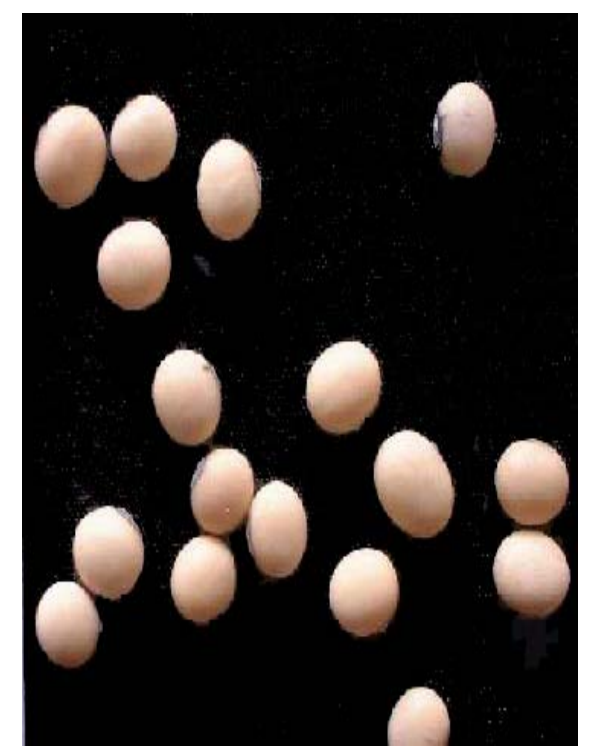

Figure 2: Glycine max seeds

Since no approaches have been attempted to detect antibacterial activity from this plant species, although it was reported that Glycine wightii demonstrated good antibacterial activity against $S$. aureus [8], therefore this study tried to discover the plant seed activity among four types of bacteria using different extracts.

\section{Materials and methods}

\section{Plant material}

Glycine max L. subjected to Magnoliophyta phylum, Magnoliopsida class, Fabales order, Fabaceae family [9]. Soybean seeds were purchased from the local market in Mosul city Nineveh province, and identified at College of Science Department of Biology.

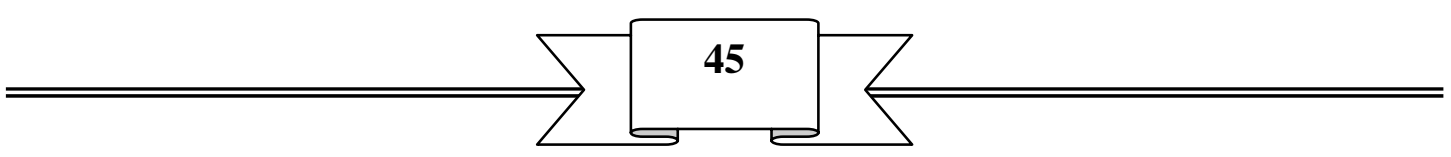




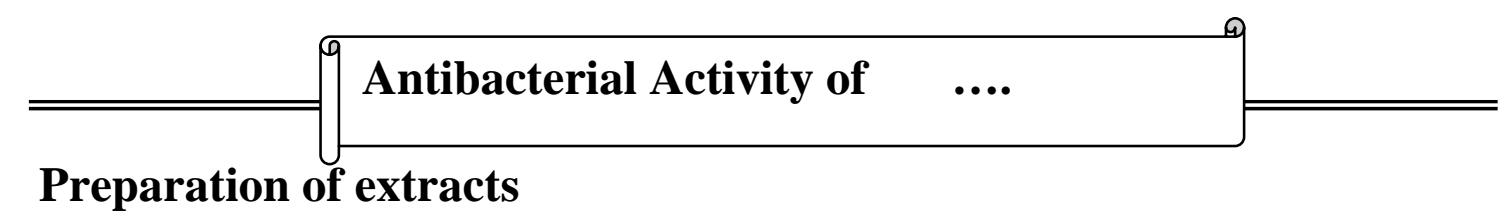

Soybean seeds were grinded to powder using an electrical blender, three different solvents were used (petroleum ether, ethanol and chloroform) to obtain different extracts.

\section{Petroleum ether, ethanol and chloroform extracts}

Plant material (seeds) were extracted using a soxhlet extractor with solvents of increasing polarity [10] beginning with petroleum ether followed by ethanol then chloroform, each extraction was carried out for 8-10 hours continuously until the used solvents turned pure and colorless. The solvents were removed using a rotary vacuum evaporator at $40^{\circ} \mathrm{C}$ to give concentrated extracts which were frozen and freeze-dried until use.

\section{Preparation of extract concentrations}

1gm of each extract (petroleum ether, ethanol and chloroform) was dissolved in 5ml DMSO (Dimethylsulfoxide) to give an extract with concentration $200 \mathrm{mg} / \mathrm{cm}^{3}$ which was used as a standard concentration in providing next dilutions $\left(100,50,25\right.$ and $\left.12.5 \mathrm{mg} / \mathrm{cm}^{3}\right)$, then were sterilized via pasturalization at $62^{\circ} \mathrm{C}$ for 15 minutes [11].

\section{Tested bacterial strains}

The microorganisms used included two Gram positive bacteria, Staphylococcus aureus, Bacillus cereus and two Gram negative bacteria, Klebsiella pneumoniae, and Pseudomonas aeruginosa which all had been obtained and identified at Department of Biology, College of Science, University of Mosul, and were further diagnosed by using characteristics features to insure.

\section{Preparation of inoculum}

All microorganisms were cultured overnight at $37^{\circ} \mathrm{C}$ in sterile Nutrient broth (Oxoid) and used as inoculum. The turbidity of the suspensions were adjusted to the McFarland 0.5 turbidity standard.

\section{Antibacterial activity}

The antibacterial tests were performed using agar-well diffusion method [12]. Agar plates were prepared using sterile Nutrient agar (Oxoid). The bacterial inoculum was evenly spread onto the surface of the agar plates using sterile swab sticks. Wells (6 $\mathrm{mm}$ diameter) were

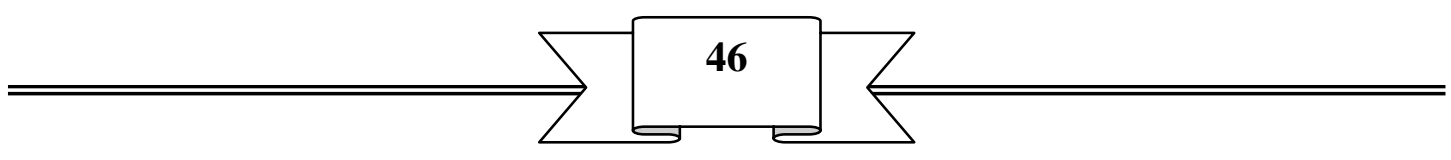




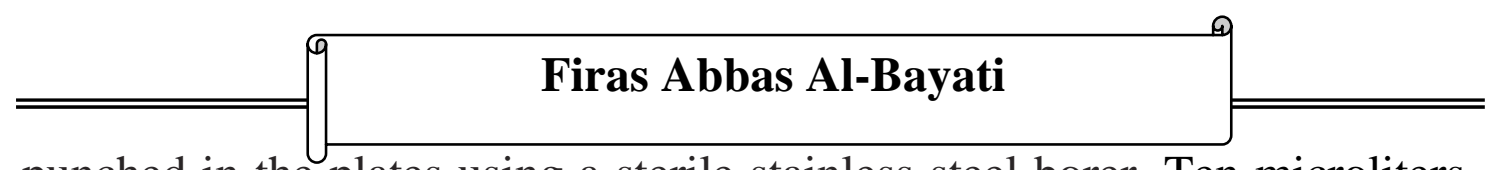

punched in the plates using a sterile stainless steel borer. Ten microliters of each extract concentrations were added in each well. Ten microliters of DMSO per well was used as a negative control. Antibiotic discs

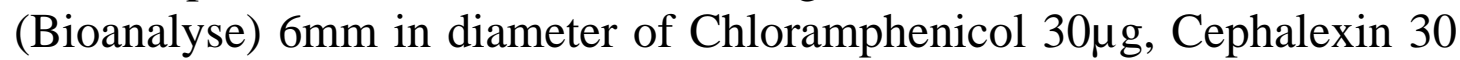
$\mu \mathrm{g}$, Tetracycline $30 \mu \mathrm{g}$ and Gentamycin $10 \mu \mathrm{g}$ were used as positive controls. Diffusion of the extracts and DMSO was allowed at room temperature for 30 minutes before incubating at $37^{\circ} \mathrm{C}$ for $24 \mathrm{~h}$. The plates were observed for the presence of inhibition of bacterial growth that was indicated by a clear zone around the wells. The size of the zones of inhibition was measured and the antibacterial activity expressed in terms of the average diameter of the zone inhibition in millimeters. The absence of a zone inhibition was interpreted as the absence of activity. Each experiment was tested in triplicate.

\section{Result and Discussion}

Study results showed various inhibitory effects of different extracts from G. max seeds against tested bacteria via agar-well diffusion method, (Table 1) revealed that petroleum ether extract was active against $S$. aureus and Ps. aeruginosa with inhibition zones of 15 and $16 \mathrm{~mm}$ in diameter respectively, using the extract concentration $200 \mathrm{mg} / \mathrm{cm}^{3}$, this extract concentration showed close or even action against Ps. aeruginosa compared with the antibiotic Gentamycin, meanwhile the concentrations (50, 25 and $12.5 \mathrm{mg} / \mathrm{cm}^{3}$ ) achieved weak activity against mentioned bacteria, this can be resulted by small quantity of active components in the extract, the results also revealed the complete resistance of $B$. cereus and Kleb. pneumoniae against the petroleum ether extract, this can be attributed to the defensive agents of these bacteria such as plasmid resistance, in addition to capsule secretion by Kleb. pneumoniae which is a general bacterial defensive factor against antibiotics $[13,14]$.

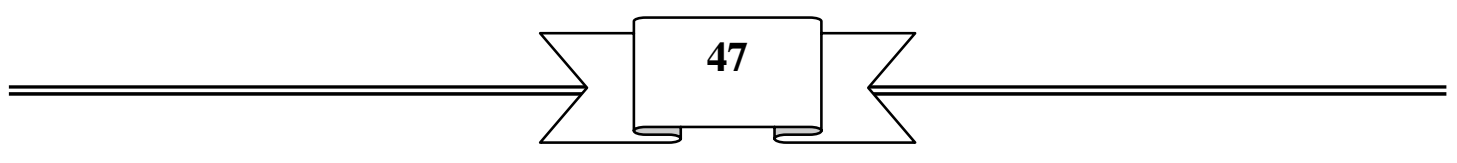


Table 1: Antibacterial activity of petroleum ether extract from Glycine max seeds.

\begin{tabular}{|c|c|c|c|c|c|c|c|c|c|}
\hline \multirow{2}{*}{ Bacteria } & \multicolumn{5}{|c|}{$\begin{array}{l}\text { Petroleum ether extract } \\
\text { concentrations }\left(\mathrm{mg} / \mathrm{cm}^{3}\right)\end{array}$} & \multicolumn{4}{|c|}{ Antibiotics } \\
\hline & 200 & 100 & 50 & 25 & 12.5 & C & CL & TE & CN \\
\hline Staphylococcus aureus & 15 & 14 & 11 & 10 & 9 & 21 & 15 & 22 & 19 \\
\hline Bacillus cereus & - & - & - & - & - & 20 & 12 & 23 & 18 \\
\hline Klebsiella pneumoniae & - & - & - & - & - & 17 & 11 & 20 & 17 \\
\hline $\begin{array}{l}\text { Pseudomonas } \\
\text { aeruginosa }\end{array}$ & 16 & 12 & 10 & 8 & 8 & 18 & 19 & 24 & 16 \\
\hline
\end{tabular}

- : No activity, C: Cloramphenicol, CL: Cephalexin, TE: Tetracycline, $\mathrm{CN}$ : Gentamycin.

From (Table 2) it can be seen that ethanol extracts from soybean seeds demonstrated good inhibitory activity against all tested bacteria, with inhibition zones between $9-18 \mathrm{~mm}$ in diameter, B. cereus (Figure 3) and Kleb. pneumoniae showed high susceptibility to ethanol extract in reversal of petroleum ether extract, compared with the antibiotic Cephalexin, the calculated zones reached 18 and $16 \mathrm{~mm}$ in diameter respectively, this may refer to the ability of the ethanol solvent in dissolving active components from plants, it was also noticed that the minimum extract concentrations (25 and $12.5 \mathrm{mg} / \mathrm{cm}^{3}$ ) were inactive in achieving antibacterial activities against tested bacteria except $B$. cereus which showed weak sensitivity towards these concentrations, and the proportion between activity and extract concentration was direct.

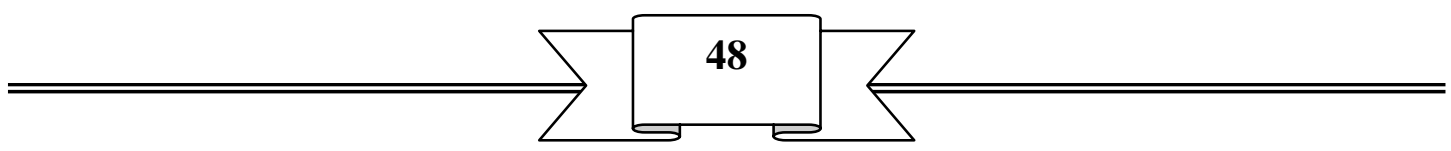




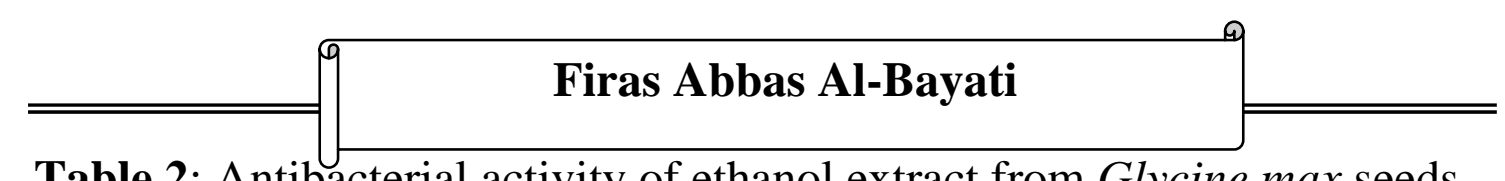

Table 2: Antibacterial activity of ethanol extract from Glycine max seeds.

\begin{tabular}{|l|c|c|c|c|c|c|c|c|c||}
\hline \multirow{2}{*}{ Bacteria } & \multicolumn{5}{|c|}{$\begin{array}{c}\text { Ethanol extract } \\
\text { concentrations (mg/ cm }\end{array}$} & \multicolumn{5}{c|}{ Antibiotics } \\
\cline { 2 - 11 } & $\mathbf{2 0 0}$ & $\mathbf{1 0 0}$ & $\mathbf{5 0}$ & $\mathbf{2 5}$ & $\mathbf{1 2 . 5}$ & $\mathbf{C}$ & $\mathbf{C L}$ & $\mathbf{T E}$ & $\mathbf{C N}$ \\
\hline \hline Staphylococcus aureus & 13 & 11 & 10 & - & - & 21 & 15 & 22 & 19 \\
\hline Bacillus cereus & 18 & 13 & 11 & 9 & 9 & 20 & 12 & 23 & 18 \\
\hline Klebsiella pneumoniae & 16 & 13 & 10 & - & - & 17 & 11 & 20 & 17 \\
\hline $\begin{array}{l}\text { Pseudomonas } \\
\text { aeruginosa }\end{array}$ & 12 & 10 & 9 & - & - & 18 & 19 & 24 & 16 \\
\hline
\end{tabular}

- : No activity, C: Cloramphenicol, CL: Cephalexin, TE: Tetracycline, $\mathrm{CN}$ : Gentamycin.

Our results indicated that the chloroform extract concentration $\left(200 \mathrm{mg} / \mathrm{cm}^{3}\right)$ from soybean seeds had moderate activity against $S$. aureus, Kleb. pneumoniae and Ps. aeruginosa (Figure 4) with inhibition zones between $13-16 \mathrm{~mm}$ in diameter, these results were better than what the antibiotic Cephalexin achieved against S. aureus and Kleb. pneumoniae (Table 3). The investigation also showed that chloroform extract concentrations (25 and $12.5 \mathrm{mg} / \mathrm{cm}^{3}$ ) showed weak inhibitory activities against $S$. aureus only, meanwhile other types resisted these concentrations, it was also noticed that $B$. cereus resisted the chloroform extract using all concentrations, this can be due to the scanty of antibacterial active components in chloroform extracts, in addition to the cooperating role between active compounds in showing inhibitory properties, if one or more of these compounds are separated it may decrease extract activity[15].

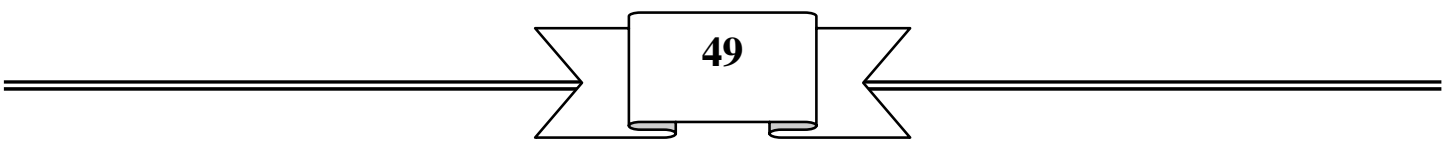


Table 3: Antibacterial activity of chloroform extract from Glycine max seeds.

\begin{tabular}{|c|c|c|c|c|c|c|c|c|c|}
\hline \multirow{2}{*}{ Bacteria } & \multicolumn{5}{|c|}{$\begin{array}{c}\text { Chloroform extract } \\
\text { concentrations }\left(\mathrm{mg} / \mathrm{cm}^{3}\right)\end{array}$} & \multicolumn{4}{|c|}{ Antibiotics } \\
\hline & 200 & 100 & 50 & 25 & 12.5 & C & CL & TE & CN \\
\hline Staphylococcus aureus & 16 & 13 & 10 & 9 & 9 & 21 & 15 & 22 & 19 \\
\hline Bacillus cereus & - & - & - & - & - & 20 & 12 & 23 & 18 \\
\hline Klebsiella pneumoniae & 13 & 9 & 8 & - & - & 17 & 11 & 20 & 17 \\
\hline $\begin{array}{l}\text { Pseudomonas } \\
\text { aeruginosa }\end{array}$ & 15 & 14 & 11 & - & - & 18 & 19 & 24 & 16 \\
\hline
\end{tabular}

- : No activity, C: Cloramphenicol, CL: Cephalexin, TE: Tetracycline, $\mathrm{CN}$ : Gentamycin.

The differences in extract activity against tested bacteria may be attributed to the cell wall complexion, muco polysaccharide extra cellular substances, in addition to the chemical complexion of bacterial cell wall and the number of its layers which also achieves resistance against antibiotics, and the role of cell wall pores in substance insertion inside bacterial cells, and ability of bacteria in changing the diameter of these pores so it can prevent large amount of substance insertion [16].

Since soybean oil has a high proportion of unsaturated fatty acid, and contain considerable levels of phenolic compounds, which are known to be synthesized by plants in response to microbial infection [17], it should not be surprising that they have been found in vitro to be effective antimicrobial substances against a wide array of microorganisms. Their activity is probably due to their ability to complex with extracellular and soluble proteins and to complex with bacterial cell walls [18].

Soybean seeds also contain levels of flavones which are phenolic structures containing one carbonyl group [19], these compounds exhibit

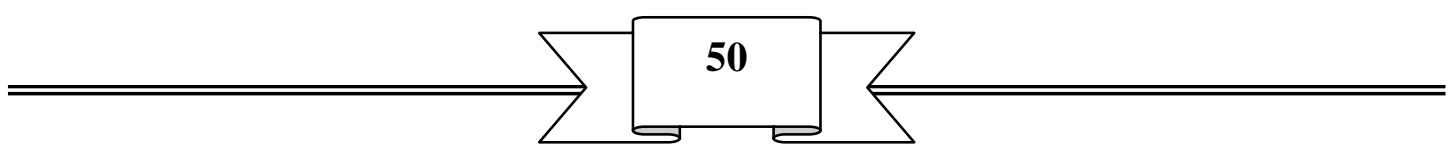




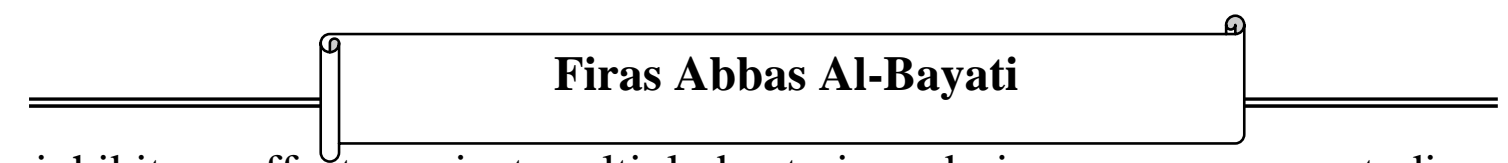

inhibitory effects against multiple bacteria and viruses, numerous studies have documented this effectiveness of flavonoids [20,21].

Finally all the extracts from G. max seeds showed weak activity against tested bacteria compared with the antibiotic Cloramphenicol, Tetracycline and Gentamycin, this can be attributed to small amount of active compounds in the used extract concentrations, and our conclusion could have been different if we used extract concentrations greater than $200 \mathrm{mg} / \mathrm{cm}^{3}$ due to the direct proportion between inhibitory activity and extract concentration in this study.

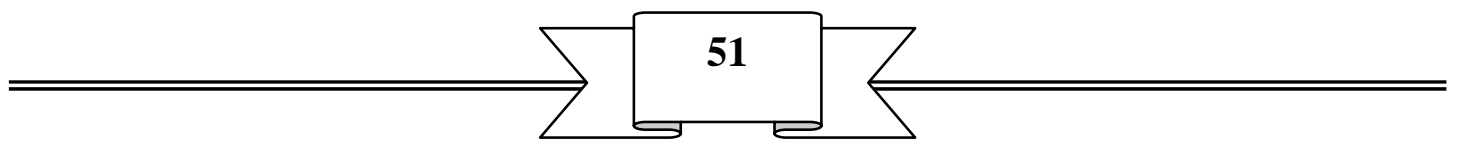



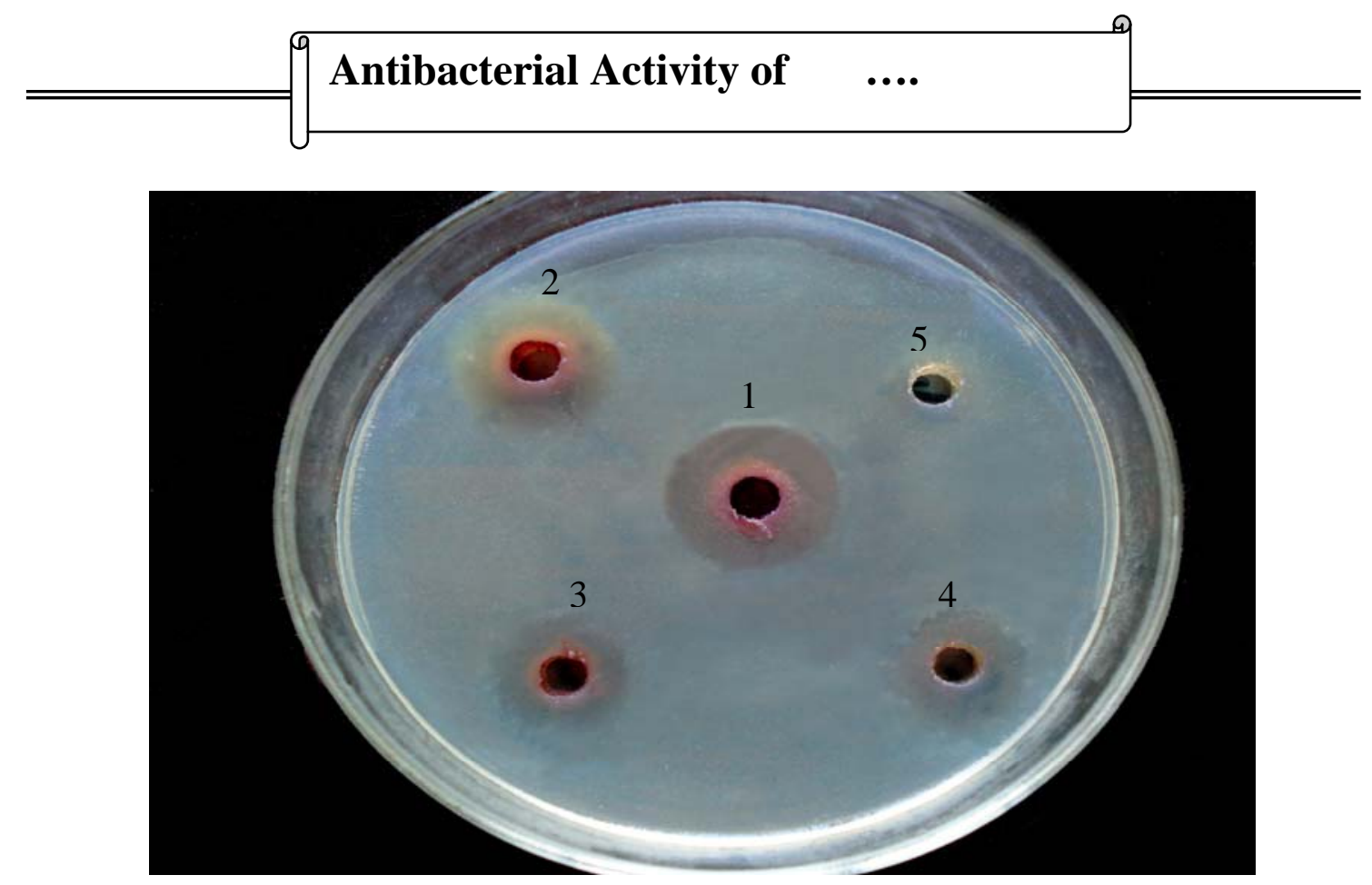

Figure 3: Effect of ethanol extract concentrations from G. max seeds against B.cereus $1\left(200 \mathrm{mg} / \mathrm{cm}^{3}\right), 2\left(100 \mathrm{mg} / \mathrm{cm}^{3}\right), 3\left(50 \mathrm{mg} / \mathrm{cm}^{3}\right)$, $4\left(25 \mathrm{mg} / \mathrm{cm}^{3}\right), 5\left(12.5 \mathrm{mg} / \mathrm{cm}^{3}\right)$.

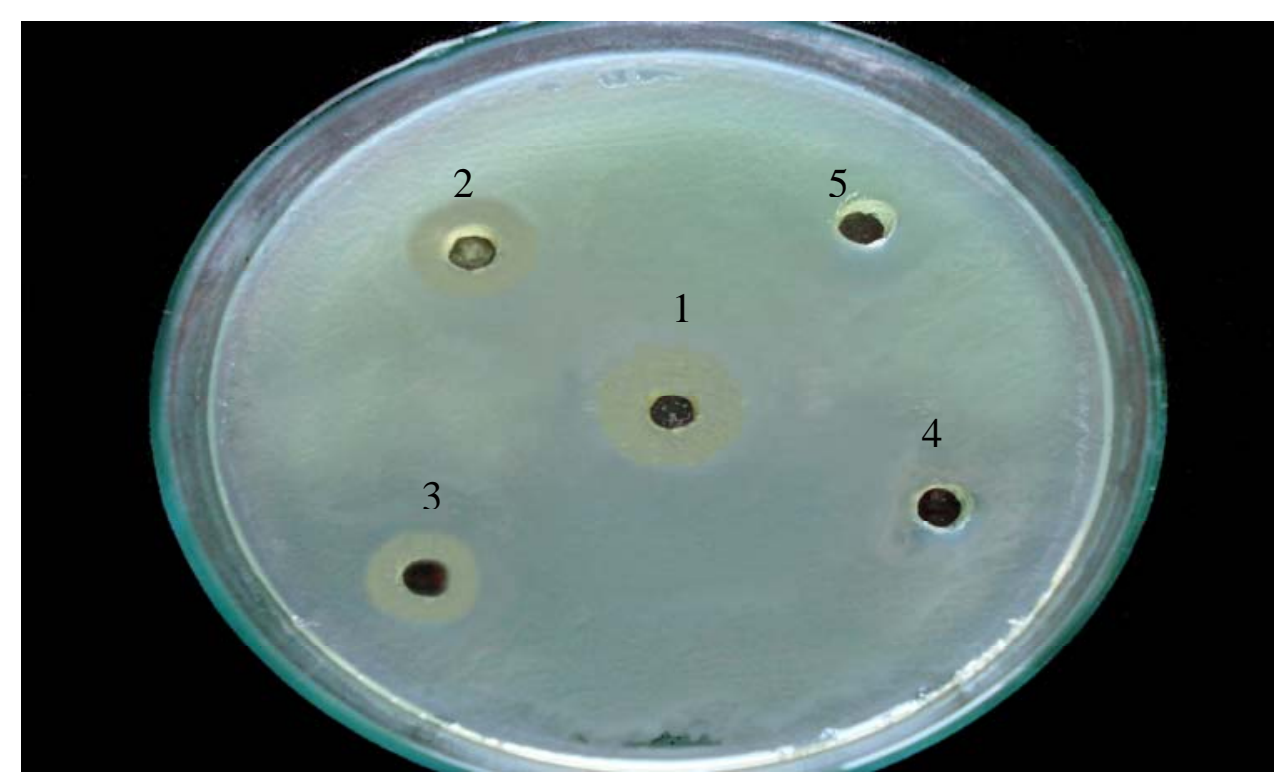

Figure 4: Effect of chloroform extract concentrations from G. max seeds against $P$ s. aeruginosa $1\left(200 \mathrm{mg} / \mathrm{cm}^{3}\right), 2\left(100 \mathrm{mg} / \mathrm{cm}^{3}\right), 3\left(50 \mathrm{mg} / \mathrm{cm}^{3}\right)$, $4\left(25 \mathrm{mg} / \mathrm{cm}^{3}\right), 5\left(12.5 \mathrm{mg} / \mathrm{cm}^{3}\right)$.

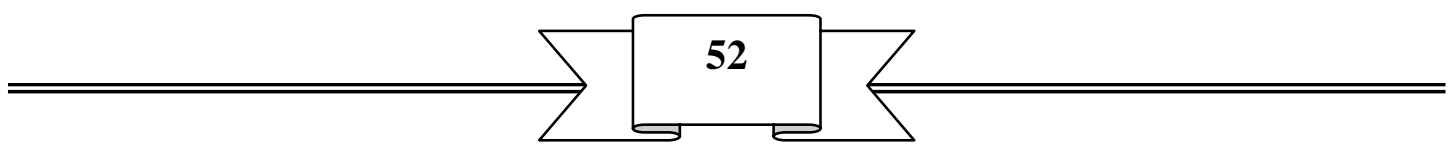




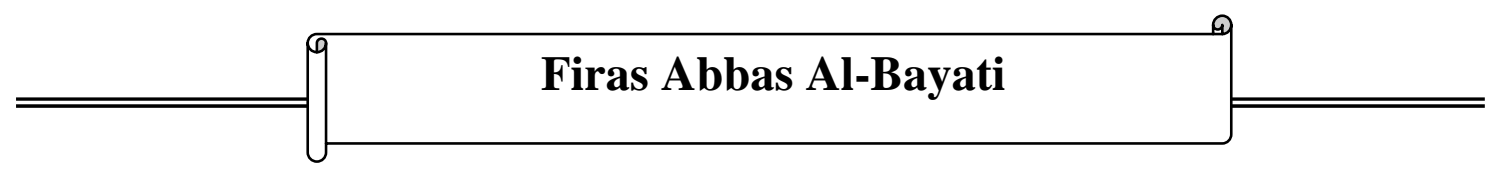

\section{References}

1. Cragg, G., Newman, D., Ethnomedicine and Drug Discovery., 23-37 (2002).

2. Cragg, G., Newman, D. and Snader, K., J. of Natural Products, 60: 5260 (1997).

3. Ramzi, A., Mothanaa, A. and Lindequistb, U., J. of Ethnopharmacology, 96: 177-181 (2005).

4. Mustafa, P., and Mustafa, K., Food Research International, 36: 10731080 (2003).

5. Duke, J., Timber Press, Portland, OR. (1990).

6. Maffeia, M. and Mucciarelli, M., Field Crops Research, 84: 229-240 (2003).

7. Van Rutha, S., Shakerb, E., Morrisseya, P., Food Chemistry, 75: 177184 (2001).

8. Boera, H., Koola, A., Brobergb, A., Mzirayc, W., Hedberga., I. and Levenforsd, J., J. of Ethnopharmacology, 96: 461-469 (2005).

9. Blackman, S., Obendorf, R. and Leopold, A., Plant Physiol., 100: (1) 225-230 (1992).

10. Ashnagar, A., Naseri, N. and Hussieni, S., First Seminar of Medical and Natrual Products Chemistry, Shiraz, Iran (2005).

11. Erturk, O., Kati, H., Yayli, N. and Demurbau, Z., Turk J. Biol., 30: 17-21 (2006).

12. National Committee for Clinical Laboratory Standards, Pennsylvania, USA, M2-A5 (1993).

13. Shale, T., Stirk, W. and Staden, J., Journal of Ethnopharmacology, 67: 347-354 (1999).

14. Haslam, E., J. Nat. Prod., 59: 205-215 (1996).

15. Cowan, M., Clinical Microbiology Review, 12: 564-582 (1999).

16. Berger-Bächi, B., Int. J. Med. Microbiol., 292: 27-35 (2002).

17. Dixon, R., Dey, P. and Lamb, C., Adv. Enzymol., 55: 1-69 (1983).

18. Vamos-Vigyazo, L., Crit. Rev. Food Sci. Nutr., 15: 49-127 (1981).

19. Fessenden, R., and Fessenden, J., 2nd ed. Willard Grant Press, Boston, Mass. (1982).

20. Pantazis, P., J. Biomed. Sci., 3: 14-19 (1996).

21. Middleton, E., Kandaswami, C., Chapman \& Hall, London, 619-652 (1994).

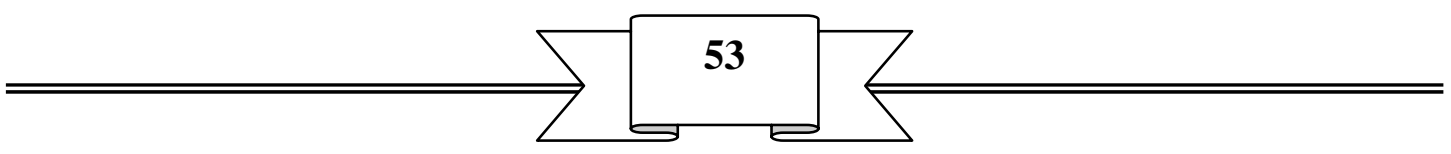

